\title{
Free trade or just trade? The world trade organisation, human rights and development (Part 2)
}

\author{
CEPHAS LUMINA
}

Independent Expert of the United Nations Human Rights Council on the effects of foreign debt and other related international financial obligations of States on the full enjoyment of all human rights, particularly economic, social and cultural rights

Extraordinary Professor, Centre for Human Rights, University of Pretoria

\subsection{The TRIPS Agreement and Human Rights}

The TRIPS Agreement (or "TRIPS") was adopted in 1994 following intense pressure exerted by the US and other industrialized countries. ${ }^{100}$ Prior to the adoption of TRIPS, the international framework for the regulation and protection of intellectual property rights consisted of a few GATT rules and a number of conventions, most of which were and still are administered by the World Intellectual Property Organisation (WIPO). ${ }^{101}$ At the national level, patent protection varied between countries. While some countries granted patents for pharmaceutical product and process inventions, others allowed patent protection only with respect to process inventions. Many did not grant any form of protection for inventions in the

100 The TRIPS Agreement is contained in Annex 1C to the Marrakesh Agreement Establishing the WTO. According to Correa, the developing countries accepted the TRIPS Agreement partly because of "the expectation of increased market access for agricultural products and textiles, and ... the fear that if they did not agree they would be increasingly vulnerable to unilateral arm-twisting by the major powers". See Correa CM Trade Related Aspects of Intellectual Property Rights: A Commentary on the TRIPS Agreement (2007) 15. See also Velasquez G and Boulet P Globalization and Access to Drugs: Implications of the WTO/TRIPS Agreement, Health and Drugs DAP Series No 7, 2 ed (1999) 40; Gervais D The TRIPS Agreement: Drafting History and Analysis (2003) 3-51; Hoekman B and Kostecki M The Political Economy of the World Trading System: The WTO and Beyond (2001) 297; Thomas and Meyer (fn 8 above) 259.

101 Gervais (fn 100 above) 5-10. WIPO administers two main international treaties on intellectual property: the Paris Convention for the Protection of Industrial Property 1967 and the Berne Convention for the Protection of Literary and Artistic Works 1971. 
pharmaceutical sector.102 Further, the period of patent protection varied significantly between countries.

In response to the perceived inadequacies of the existing rules concerning the absence of detailed rules on the enforcement of intellectual property rights before national judicial authorities and the lack of an effective international dispute settlement system, the US and the European Community (now called the European Union) argued for the inclusion of intellectual property matters into the Uruguay Round trade negotiations. ${ }^{103}$ Unlike the pre-TRIPS conventions on intellectual property rights, the TRIPS Agreement provides for enforcement of such rights. In particular, it links the obligations of the TRIPS Agreement with those of the WTO Agreement and thus ensures that a violation of the TRIPS Agreement can, in certain circumstances, be punished through the use of trade-related sanctions. ${ }^{104}$ These provisions essentially reflect the wishes of the US and other developed countries which had contended that the mere guarantee of rights was insufficient and that holders of intellectual property rights should be afforded the opportunity to effectively exercise them. ${ }^{105}$

The TRIPS Agreement stipulates some general obligations for compliance, by all WTO Member States irrespective of their level of development, with certain minimum standards of protection of intellectual property, which are in practice the standards applied in developed countries. ${ }^{106}$ However, in recognition of the difficulties that some Members might encounter in implementing it, TRIPS provides for progressive implementation of its obligations. Thus, developing countries and least developed countries (LDCs), were allowed five years and 11 years (with the possibility of an extension), respectively, to implement the obligations contained in the Agreement (with the exception of articles 3, 4 and 5). The Doha Declaration extends this delay in relation to patents on medicines to 2016 (see below).

It is worthy of note that, unlike the other WTO agreements, the TRIPS Agreement does not aim to liberalize trade. Rather, its purpose is to establish rules for the acquisition of intellectual property and the control over the production and trade of the products derived therefrom. ${ }^{107}$

\section{(a) Overview of the Main Provisions}

The TRIPS Agreement extends the application to intellectual property rights of three GATT principles, namely, national treatment, most-favoured nation treatment (MFN) and transparency; stipulates general rules to be met by the procedures for the acquisition and maintenance of intellectual property rights; and provides for

\footnotetext{
102 Hestermeyer (fn 71 above) 11.

103 See Thomas and Meyer (fn 8 above) 256.

104 Ibid 252.

${ }^{105}$ Correa (fn 100 above) 8.

106 Velasquez and Boulet (fn 100 above) 40. See also Correa (fn 100 above) 8.

107 Correa (fn 100 above).
} 
transitional arrangements. Article 1 sets out the nature and scope of the obligations under the Agreement stating that Members shall give effect to its provisions and that they may provide more extensive protection than the minimum set by the Agreement. It further states that Members are at liberty to determine "the appropriate method" of implementing TRIPS provisions "within their own legal systems and practice".

The objectives of the TRIPS Agreement as set out in article 7 essentially focus on contributing "to the promotion of technological innovation and to the transfer and dissemination of technology ... in a manner conducive to social and economic welfare, and to a balance of rights and obligations". ${ }^{108}$ In terms of article 8 (which clarifies the application, scope and coverage of the Agreement) Members are free to adopt measures relating to public health and nutrition or to promote the public interest in certain sectors provided that such measures are consistent with the Agreement. Further, the provision allows Members to adopt measures to prevent anti-competitive abuse of intellectual property rights by right holders.

Part II of the Agreement provides for minimum standards of protection that WTO Members must respect concerning the availability, scope and use of specific categories of intellectual property rights taking into account the national treatment and MFN principles which are set out in articles 3 and 4. The agreement protects seven types of intellectual property: patents, copyright, trademarks, industrial designs, geographical indications, layout designs of integrated circuits and undisclosed information. ${ }^{109}$ The most important of these from the perspective of access to medicines are the provisions concerning patents.

Part III of the Agreement establishes specific obligations concerning the enforcement of the protections provided for intellectual property. In particular, it specifies a number of rights and remedies that Members must extend to rightholders under their domestic laws. ${ }^{110}$ Part IV concerns dispute prevention and settlement while part VI provides for transitional arrangements.

\section{(b) Human Rights Implications}

The TRIPS Agreement is one of the most controversial agreements under the WTO in terms both of its objectives and consequences. It has a number of implications for public health, food security, biodiversity, agriculture and indigenous knowledge. ${ }^{111}$

\footnotetext{
108 The protection of intellectual property rights was introduced into the agenda of the WTO ostensibly to protect innovation by giving temporary monopolistic rents to innovative companies which are mainly located in the developed countries - in reality to protect the high-tech industries of developed countries from developing country competition, particularly from South East Asia. See McCulloch Winters and Cirera (fn 24 above) 208. According to Oxfam, the claims that intellectual property protection and the resulting monopoly profits can sustain innovation are debatable. See Oxfam (2006) fn 4 above at 6-8.

109 Arts 15-40.

110 Arts 42-61.

111 See UNDP Human Development Report (1999).
} 
All of these relate to the human rights standards set out in international human rights instruments, most notably, in articles 11 to 15 of the International Covenant on Economic, Social and Cultural Rights (ICESCR). In a resolution adopted in August 2000, the Sub-Commission on the Promotion and Protection of Human Rights noted the following:

[A]ctual or potential conflicts exist between the implementation of the TRIPS Agreement and the realisation of economic, social and cultural rights in relation to, inter alia, impediments to the transfer of technology to developing countries, the consequences for the enjoyment of the right to food, of plant variety rights and the patenting of genetically modified organisms, 'bio-piracy' and the reduction of communities' (especially indigenous communities') control over their own genetic and natural resources and cultural values, and restrictions on access to patented pharmaceuticals and the implications for the enjoyment of the right to health. ${ }^{112}$

The Sub-Commission proceeded to declare that:

[S]ince the implementation of the TRIPS Agreement does not adequately reflect the fundamental nature and indivisibility of all human rights, including the right of everyone to enjoy the benefits of scientific progress and its applications, the right to health, the right to food, and the right to self-determination, there are apparent conflicts between the intellectual property rights regime embodied in the TRIPS Agreement, on the one hand, and international human rights law, on the other. ${ }^{113}$

It further requested "the World Trade Organisation, in general, and the Council on TRIPS during its ongoing review of the TRIPS Agreement, in particular", to take fully into consideration "the existing State obligations under international human rights instruments". 114

What follows is a discussion of the implications of TRIPS for the realisation of the right to health in general and access to medicines in particular.

\section{(c) TRIPS and the Right to Health}

The right to health is a fundamental human right which is indispensable for the enjoyment of other rights. While it is generally considered to be part of the group of economic, social and cultural rights (as opposed to civil and political rights) the right to health is closely related to and dependent upon the realisation of other human rights, including the rights to food, housing, work, education, human dignity, non-discrimination, equality, life, privacy, access to information, and the prohibition of torture.

First explicitly formulated as a "right" in the Preamble to the Constitution of the World Health Organisation (WHO) in 1946, the right to health has been

112 Resolution on Intellectual Property Rights and Human Rights, Doc.E/CN.4/Sub.2/2000/7, 17 August 2000, preamble.

113 Ibid para 2.

114 Ibid para 8. 
incorporated in varying formulations in a wide range of international legal instruments. The main universal human rights instruments providing for the right to health include the Universal Declaration of Human Rights (UDHR); ${ }^{115}$ the ICESCR; 116 Convention on the Elimination of All Forms of Discrimination against Women (CEDAW); ${ }^{117}$ Convention on the Rights of the Child (CRC); ${ }^{118}$ Convention on the Elimination of All Forms of Racial Discrimination (ICERD); ${ }^{119}$ Convention on the Protection of the Rights of All Migrant Workers and Members of their Families (CMW), ${ }^{120}$ and the Convention on the Rights of People with Disabilities. ${ }^{121}$ Other international instruments relating to, or enshrining the right to health are the Geneva Conventions of $1949^{122}$ and the Additional Protocols of $1977^{123}$ which oblige States Parties to provide medical care for the wounded; the Declaration on the Protection of Women and Children in Emergency and Armed Conflict; the Body of Principles for the Protection of All Persons Under Any Form of Detention or Imprisonment; the Standard Minimum Rules for the Treatment of Prisoners; the Declaration on the Rights of Mentally Retarded Persons; and the Declaration on the Rights of Disabled Persons.

Article 12 of the ICESCR provides that everyone has the right "to the highest attainable standard of physical and mental health". In terms of article 12(2) (c), States Parties must take the necessary steps for "the prevention, treatment and control of epidemic, endemic, occupational and other diseases". The ESCR Committee has interpreted this provision to mean the establishment of prevention and education programmes for behaviour-related health concerns such as sexually transmitted diseases, in particular HIV/AIDS, and those adversely affecting sexual and reproductive health, and the promotion of social determinants of good health, such as environmental safety, education, economic development and gender

115 Article 25.

116 Article 12.

117 Article 12 guarantees to women the right to health care, focusing on equal access to health care facilities for women. In particularly, it provides for the provision free of charge of pre and post natal healthcare by states. Article 12(d) enjoins states to ensure that rural women have "access to health care facilities, including information, counselling and services in family planning".

118 Article 24 guarantees the right of children to "the highest attainable standard of health".

${ }^{119}$ Article 5(e) (IV) guarantees the right of everyone, without distinction as to race, colour or national or ethnic origin, among others, the right to public health and medical care.

120 Article 27 enjoins states parties to provide emergency medical care to migrant workers and members of their families.

121 Article 25 guarantees the right of persons with disabilities to enjoy the highest attainable standard of health without discrimination on the basis of disability.

${ }^{122}$ Article 3(2) of the Convention (I) for the Amelioration of the Condition of the Wounded and Sick in Armed Forces in the Field; Convention (II) for the Amelioration of the Condition of the Wounded, Sick and Shipwrecked Members of the Armed Forces at Sea; Convention (III) relative to the Treatment of Prisoners of War; and Convention (IV) relative to the Protection of Civilian Persons in Time of War. The four conventions were adopted on 12 August 1949.

123 Protocol Additional to the Geneva Conventions of 12 August 1949, and Relating to the Protection of Victims of International Armed Conflicts (Protocol I), articles 10 and 11 and Protocol Additional to the Geneva Conventions of 12 August 1949, and Relating to the Protection of Victims of NonInternational Armed Conflicts (Protocol II), article 7. Both Protocols were adopted on 8 June 1977. 
equity. ${ }^{124}$ The control of diseases concerns states' duties (individually and collectively) to make available relevant technologies, the implementation or enhancement of immunizations programmes and other strategies for controlling infectious diseases. ${ }^{125}$ Under article 12(2)(d) of the ICESCR, States Parties must create "conditions which would ensure to all medical attention in the event of sickness". According to General Comment No 14 adopted by the ESCR Committee, this includes, inter alia, the provision of essential drugs.

The ESCR Committee has identified four interrelated and essential elements of the right to health: availability of sufficient and functioning public health and healthcare facilities, goods and services; accessibility of health facilities, goods and services to everyone on a non-discriminatory basis; acceptability (or cultural appropriateness) of health facilities, goods or services; and quality of health facilities, goods and services (which must be scientifically and medically appropriate and of good quality).

In the context of the current discussion, the concept of accessibility implies that government policies must aim to make drugs available for all who need them, and at affordable prices. ${ }^{126}$

\section{(d) Constraints on Access to Medicines}

As stated above, accessibility is one of the key elements of the right to health. Based on human rights principles, universal access requires that medicines not only be available, ${ }^{127}$ acceptable and of good quality, but also affordable to all. However, in many developing countries there are numerous existing barriers to access to appropriate health care. These include non-affordability of drugs, poor health care infrastructure, poor diagnosis, and inadequate funding. ${ }^{128}$ It is important to note in

124 See CESCR General Comment No 14: The Right to the Highest Attainable Standard of Health, Doc.E/C.12/2000/4 (2000) para 16.

125 Ibid.

126 In 2001, the UN General Assembly unanimously embraced equitable access to care and treatment as a fundamental component of a comprehensive and effective global HIV response. See UN Declaration of Commitment on HIV/AIDS, Resolution adopted by the General Assembly, Doc.A/Res/S26/2, 2 August 2001.

127 In Free Legal Assistance Group and Others v Zaire (2000) AHRLR 74 (ACHPR 1995), the African Commission on Human and Peoples' Rights found, inter alia, that the shortage of medicine constituted a violation of the right to enjoy the best attainable state of physical and mental health. The Commission endorsed the definition of the right to health put forth by the UN Committee on the Elimination of Discrimination against Women. In its General Recommendation No 24, the Committee defined the right to health to include socio-economic factors: "The Committee notes that the full realisation of women's right to health can be achieved only when States parties fulfil their obligations to respect, protect and promote women's fundamental human right to nutritional well-being throughout their life-span by means of a food supply that is safe, nutritious and adapted to local conditions".

128 Dommen (fn 2 above) 23. See also Mushayavanhu D "The realisation of access to HIV and AIDSrelated medicines in Southern African countries: Possibilities and actual realisation of international law obligations" in Viljoen F and Precious S (eds) Human Rights under Threat: Four Perspectives on 
this regard that a country's level of development does not relieve it of responsibility to ensure full realisation of the right to health. Thus, in Purohit and Moore $v$ The Gambia $^{129}$ the African Commission on Human and Peoples' Rights held that while many African countries faced the "problem of poverty" which rendered them incapable of providing the necessary amenities, infrastructure and resources that facilitate the full enjoyment of the right to health, article 16 of the Charter imposed an obligation on the part of States parties to "take concrete and targeted steps, while taking full advantage of their available resources" to ensure that the right to health is fully realised in all its aspects without discrimination of any kind.

Although the precise effect of the TRIPS Agreement may vary from country to country, it has been asserted that patent protection enhances the likelihood of higher drugs prices. ${ }^{130}$ Numerous empirical studies concerning the price effects of patents indicate that patents lead to significant price increases which are generally in excess of 100 per cent. ${ }^{131}$ In a complaint lodged in 2002 by the AIDS Law Project with the South African Competition Commission alleging that GlaxoSmithKline and Boehringer Ingelheim were acting in violation of the Competition Act No 89 of 1998 by charging excessive prices for their anti-retroviral drugs (ARVs) to the detriment of consumers, the complainants submitted that a comparative analysis of the patented medicines and generic alternatives indicated that the patented drug was generally priced at 230 per cent of the generic. ${ }^{132}$

The observations of international organisations with responsibilities in the area of health lend succour to the foregoing claims. For example, UNAIDS has stated that patents have had "a severely limiting effect on access to medicines because prices

HIV, AIDS and the Law in Southern Africa (2007) 127, 130.

129 (2003) AHRLR 96 (ACHPR 2003).

130 Velasquez and Boulet (fn 100 above) 89. In circumstances where the technology of essential drugs (such as ARVs), is controlled by a few pharmaceutical companies in the developed countries that tend to charge prices well beyond what poor people can afford, TRIPS requirements have serious implications for human rights. As Baker has observed, the overall effect of the Agreement has been "to consolidate the economic power and exclusive marketing privileges" enjoyed by the pharmaceutical industry. See Baker BK Processes and Issues for Improving Access to Medicines: Willingness and Ability to Utilise TRIPS Flexibilities in Non-Producing Countries (2004)15.

131 These indicate that patents lead to significant price increases, generally in excess of 100 per cent. See, for example, Chaudhuri S Goldberg PK and Jia P "The Effects of Extending Intellectual Property Rights Protection to Developing Countries: A Case Study of the Indian Pharmaceutical Market" NBER Working Paper 10159 (2003) 31 (price increases for India estimated at between 200\% and 750\%); Fink C "How Stronger Patent Protection in India Might Affect the Behaviour of Transnational Pharmaceutical Industries" World Bank Working Paper No 2352 (2000) 42 (Indian price increases estimated at over 200\%); Correa CM Intellectual Property Rights, the WTO and Developing Countries: The TRIPS Agreement and Policy Options (2000) 35; Subramanian "The AIDS Crisis, Differential Pricing of Drugs and the TRIPS Agreement: Two Proposals" (2001) 4 Journal of World Intellectual Property 323, 324.

132 See AIDS Law Project and TAC The Price of Life: Hazel Tau and Others $v$ GlaxoSmithKline and Boehringer Ingelheim: A Report on the Excessive Pricing Complaint to South Africa's Competition Commission (2003). 
have been set that are far beyond the reach of developing countries". ${ }^{133}$ Similarly, the WHO has observed that patents "can play a significant, or even dominant, role" in preventing access to medicines in that they grant the patent holder a monopoly on a drug for the duration of the patent. ${ }^{134}$ While acknowledging that the price of ARVs "has fallen significantly in recent years", the WHO has emphasised that the cost of these drugs "remains an obstacle to access in the developing world". By December 2006, between $1.8-2.2$ million people were receiving anti-retroviral treatment in low- and middle income countries, representing 28 per cent of the estimated 7.1 million people in need. ${ }^{135}$

The high cost of pharmaceuticals poses a threat to the right to health by restricting access to medicines for poor consumers from developing countries. ${ }^{136}$ In relation to HIV/AIDS, patented versions of ARVs and other drugs used against the attendant opportunistic infections typically cost almost 15 times as much as their generic equivalents. In countries with severe health budgetary constraints, these prices almost invariably entail the exclusion of large numbers from effective treatment. ${ }^{137}$ It can be contended therefore that the TRIPS Agreement essentially impairs the right to health by hindering the ability of governments to fulfil their obligations to their citizens with respect to ensuring access to affordable medicines. It is in recognition of this reality that the General Council of the WTO adopted the Declaration on TRIPS and Public Health.

\subsection{Pharmaceutical Patents Flexibilities under TRIPS}

The TRIPS Agreement provides for measures that limit the rights of patent holders. ${ }^{138}$ These include limited exceptions under article 30 of the Agreement, compulsory licences, parallel imports and patent revocation in terms of article 32 of the Agreement. 139 These "TRIPS flexibilities", as they are commonly referred to, are significant from the perspective of the right to health in that they can enhance the ability of WTO Member States to ensure access to affordable medicines.

133 See http://www.unaids.org/eng/PolicyAndPractice/HIVTreatment/IntellectProperty/ (access confirmed: 16 February 2008).

134 See WHO/UNAIDS/MSF "Determining the patent status of essential medicines in developing countries" Health Economics and Drugs, EDM Series, No 17 (2004), WH/EDM/PAR/2004.6, at 7.

135 WHO/UNAIDS/UNICEF Towards Universal Access: Scaling up priority HIV/AIDS interventions in the health sector, Progress Report (2007) 5.

136 According to OHCHR, highly priced drugs have negative implications for the right to health. OHCHR (fn 95 above) 2. See also Eide A "The Importance of Economic and Social Rights in the Age of Economic Globalization" in Eide WB and Kracht U (eds) Food and Human Rights in Development: Legal Institutional Dimensions and Selected Topics Vol I (2005) 3, 35.

137 Oxfam (2001) fn 4 above.

138 A Member State's freedom to interpret and use these flexibilities to promote public health was reaffirmed by the 2001 WTO Doha Declaration on TRIPS and Public Health (discussed below).

139 For a discussion of these flexibilities, see Hestermeyer (fn 71 above) 229-255; Mushayavanhu (fn 128 above) 


\section{(a) Limited Exceptions}

In terms of article 30 of the Agreement, Members may provide several exceptions to the exclusive rights conferred by patents "provided that such exceptions do not unreasonably conflict with a normal exploitation of a patent and do not unreasonably prejudice the legitimate interests of the patent owner". While some commentators have favoured a broad interpretation of this provision, in CanadaPharmaceuticals, the Panel held that the limitations and exceptions permitted under article 30 had to fulfil three separate, cumulative criteria: (a) the exception must be limited or narrow in scope; (b) the exception must not unreasonably conflict with normal exploitation of the patent (i.e. the patent owner had the right to "exclude all form of competition that could detract significantly from the economic return anticipated from a patent's grant of market exclusivity"); and (c) the exception must not unnecessarily prejudice the legitimate interest of the patent owner, taking into account the legitimate interests of third parties. ${ }^{140}$ The Panel distinguished the concept of legitimate interests from that of "legal interests", holding that the latter was narrower than the former and, that the former referred to "interests that are 'justifiable' in the sense that they are supported by relevant public policies or other social norms". ${ }^{141}$

Nevertheless, it is important to note that the provision does not stipulate the various grounds on which Members may base their exceptions. Thus, Member States have wide latitude for implementing the Agreement through national laws. In this regard, it is worth recalling that under article 8(1) of the TRIPS Agreement, a Member State may adapt national regulations to the fundamental objectives of its policies in certain areas, provided these regulations do not contravene the provisions of the Agreement. Among these objectives are "public health" and nutrition. In terms of this provision:

Members may, in formulating or amending their laws and regulations, adopt measures necessary to protect public health and nutrition, and to promote the public interest in sectors of vital importance to their socio-economic and technological development, provided that such measures are consistent with the provisions of this Agreement.

It is arguable that the above provision constitutes an express recognition of measures that a Member State could adopt to guarantee accessibility to medicines. In other words, the provision affords Member States the opportunity to establish national regulations designed to guarantee access to essential and affordable drugs. ${ }^{142}$

\footnotetext{
${ }^{140}$ Canada-Patent Protection of Pharmaceutical Products - Complaint by the European Communities and their Member States, WT/DS114/R, par 7.20 (2000).

141 Ibid at par 7.69.

142 Velasquez and Boulet (fn 100 above) 19.
} 


\section{(b) Compulsory Licences}

In general, patent holders are free to exploit the patented invention or to authorize someone else to exploit it. Under article 31, however, Member States may issue compulsory licences when reasons of general or public interest (such as public health, economic development and national defence) justify it. Stated differently, governments may allow the exploitation of a patent by a third party without the patent holder's consent provided the minimum conditions stipulated by the Agreement which are aimed at protecting the legitimate interests of the patent holder are satisfied. ${ }^{143}$ Thus, for instance, the applicant for a licence must have first attempted, unsuccessfully, to obtain a voluntary licence from the right holder on reasonable commercial terms. ${ }^{144}$ If a compulsory licence is issued, adequate remuneration must still be paid to the right holder. ${ }^{145}$

However, it is not necessary to apply for a voluntary licence in cases of "national emergencies", "other circumstances of extreme urgency" or "public non-commercial use" (or "government use") or anti-competitive practices. ${ }^{146}$ The Doha Declaration recognises that public health crises, such as those relating to HIV/AIDS, tuberculosis, malaria and other epidemics, can represent a national emergency or "other circumstances of extreme urgency". ${ }^{147}$ Thus, it can be argued that ensuring the availability of essential drugs at lower cost is a public interest issue.

Compulsory licensing allows governments to make generic versions of patented drugs available and may therefore have the effect of reducing the price of medicines and ensuring access to affordable medicines. Nevertheless, many countries have

143 The minimum conditions set by the Agreement are: authorization will be granted only if the proposed user has attempted to obtain the licence on reasonable commercial terms; the scope and duration of the authorization must be limited; authorization is non-exclusive; the authorization cannot be assigned; the main objective of the authorization must be supply of the domestic market; the authorization will be suspended if the circumstances that led to it cease to exist; and the patent holder must be given adequate remuneration that takes into consideration the economic value of the authorization. It should be noted that the term "compulsory licensing" is not used in the TRIPS Agreement. Instead, article 31 refers to "other use without authorization of the right holder". Conversely, the Doha Declaration employs the term "compulsory licences" in article 5(b) which confers upon Members the right to grant compulsory licences and to determine the grounds upon which such licences are granted.

${ }^{144}$ Article 31(b).

145 Article 31(h). Nevertheless, as the Zambian case illustrates, a developing country responding to a public health crisis can determine a relatively low rate of remuneration to be adequate. In September 2004, Zambia granted a compulsory licence on medicine (the first granted by an African country) to a local company for the production of a triple-combination AIDS drug after the failure of negotiations with the patent holders. Zambia fixed the royalties at a rate not exceeding 2.5 per cent of the total sales of the product at the end of each financial year. See Republic of Zambia Ministry of Commerce, Trade and Industry Compulsory Licence No CL 01/2004, MCT1/104/1/1c (21 September 2004) cited in Hestermeyer (fn 71 above) at 249.

${ }^{146}$ Article 31(b).

147 Doha Declaration, article 5(c). 
failed to utilise this flexibility due to the uncertainty concerning the interpretation of the conditions imposed by article 31 of TRIPS and the pressure applied by developed countries not to grant compulsory licences for pharmaceuticals. ${ }^{148}$ Further, countries with no production capabilities are disadvantaged in that they cannot issue effective compulsory licences because of the requirement under article 31(f) that production under such a licence should be "predominantly for the supply of the domestic market".

\section{(c) Parallel Imports}

Parallel imports are products marketed by the patent owner or with the patent owner's permission in one country and imported into another country without the approval of the patent owner. ${ }^{149}$ This flexibility is based on the theory of exhaustion of intellectual property rights according to which the exclusive right of the patent holder to import the protected product is exhausted, and thus ends, when the product is first put on the market. While the principle is uncontested in the national context it has generated a great deal of controversy in the international context. ${ }^{150}$ It is notable, however, that the TRIPS Agreement does not explicitly mention or ban parallel imports. This lacuna gives Members wide latitude to determine their own regulatory regimes.

As in the case of compulsory licenses, parallel imports can have the effect of reducing the price of medicines by allowing the government to grant a licence for the import of cheaper versions of a patented drug.

\section{(d) Revocation of Patents}

In some cases, national patent laws provide for the revocation of or forfeiture of a patent in circumstances where the maintenance fees are not paid timely or where the conditions for the grant of a patent were not fulfilled at the time of the grant. Article 32 of TRIPS implicitly recognises the right of Member States to revoke patents by providing that "[a]n opportunity for judicial review of any decision to revoke or forfeit a patent shall be available". However, the provision does not specify the grounds of any such revocation or forfeiture. This has led to different interpretations with some Member States (such as India) arguing that the provision allows the revocation of patents on any grounds and others (such as the US) countering that such an interpretation is inconsistent with the TRIPS Agreement. 151 Nevertheless, it may be argued that the revocation of a patent can potentially lower drug prices by allowing competition and in this way enhancing access to affordable medicines.

\footnotetext{
148 Hestermeyer (fn 71 above) 253.

149 Velasquez and Boulet (fn 100 above).

150 See Hestermeyer (fn 71 above) 230.

151 Hestermeyer (fn 71 above) 253-254.
} 


\subsection{Obstacles to using TRIPS Flexibilities}

It is worthy of note that while a number of developing countries have attempted to invoke the TRIPS flexibilities to advance public health goals, they generally have encountered obstacles in the form of legal challenges by developed countries, notably the US. The South African and Brazilian attempts to ensure their citizens' access to affordable medicines are instructive.

In 2002, the South African government passed the Medicines and Related Substances Act Control Amendment Act ${ }^{152}$ in response to the HIV/AIDS epidemic and to keep medicines affordable in the country. Under section 15C of the Act the Minister of Health was empowered to limit patent rights through the use of two measures designed to ensure access to cheaper medicines: parallel imports and compulsory licences. In response, several large pharmaceutical transnational corporations (TNCs) instituted suit against the government, arguing that many provisions of the Act contravened, inter alia, the pharmaceutical industry's property rights under the South African Constitution. ${ }^{153}$ It was also contended that section 15C was inconsistent with article 27 of the TRIPS Agreement as it purportedly discriminated against pharmaceutical patents. Conversely, the South African government argued that it had a constitutional obligation to protect its citizens' right to health. For its part, the US government placed South Africa on its "Special 301" Watch List and withheld preferential treatment under the Generalized System of Preferences on selected items. However, intense national and international pressure forced the TNCs to withdraw their lawsuit and the US government to reach an agreement with the South African government. ${ }^{154}$

In 2001, the US initiated a WTO dispute settlement proceeding against Brazil concerning the latter's compulsory licensing legislation, which imposed a "local working" requirement, stipulating that a patent would be subject to compulsory licensing if the subject matter was not "worked" in Brazil.155 The US claimed that this requirement discriminated against US companies which owned Brazilian patents whose products were imported into, but not produced, in Brazil. The US alleged that this law was incompatible with the TRIPS Agreement. Brazil had produced generic anti-retroviral drugs (ARVs) without using compulsory licences because pharmaceutical patents were not recognised. However, the new legislation

152 Act No 90 of 1997.

153 Pharmaceutical Manufacturers' Association of South Africa et al $v$ President of the Republic of South Africa, Case No. 4183/98.

154 The understanding was premised on the commitment of both governments to TRIPS as well as "an appreciation of the South African Government's efforts to provide affordable health care to its people". See Department of Trade and Industry Joint Understanding between the Governments of South Africa and the United States of America available at http://lists.essential.org/pharmpolicy/msg00244.html (access confirmed: 28 March 2008).

155 Industrial Property Law, Law 9.279/96. See Request for Consultations by the United States, BrazilMeasures Affecting Patent Protection, WT/DS199/1, G/L/385, IP/D/23, 8 June 2000, and Request for the Establishment of a Panel by the United States, Brazil-Measures Affecting Patent Protection, WT/DS199/39, January 2001. 
brought Brazil in line with its WTO obligations. In order to produce new generic ARVs, the Brazilian government had to issue compulsory licences under the legislation challenged by the US. Needless to mention, the measures demanded by the US posed a direct threat to the highly successful Brazilian government programme to fight HIV/AIDS, which was largely based on Brazil's ability to manufacture affordable drugs for HIV/AIDS treatment. Ultimately, however, the parties reached a "mutually satisfactory" political settlement in which the US withdrew the case and Brazil agreed, in the event "it deems necessary to apply article 68 (of its Industrial Property Law) to grant compulsory licence on patents held by the US companies and to hold prior talks on the matter with the US Government". ${ }^{156}$ However, the US reserved its right to re-introduce the issue and threatened to "aggressively engage" any other countries that sought to utilise the "local working" requirement. ${ }^{157}$

\subsection{The Doha Declaration - a Way out of the Quagmire?}

In November 2001, the flexibility under TRIPS was clarified and enhanced by the Doha Ministerial Declaration which addressed the issue of the relationship between the TRIPS Agreement and access to medicines. ${ }^{158}$ The Declaration, which was adopted in response to the multiple controversies concerning access to drugs, especially in the context of the HIV/AIDS epidemic, recognised that:

[U]nder WTO rules no country should be prevented from taking measures for the protection of human, animal or plant life or health, or of the environment at the levels it considers appropriate, subject to the requirement that they are not applied in a manner which would constitute a means of arbitrary or unjustifiable discrimination between countries where the same conditions prevail, or a disguised restriction on international trade, and are otherwise in accordance with the provisions of the WTO Agreements. ${ }^{159}$

Paragraph 17 of the Declaration underlined the importance of implementing and interpreting the TRIPS Agreement in a manner that supports public health, by promoting both access to existing medicines and the development of new medicines.

In recognition of the "gravity of the public health problems afflicting many developing and least developed countries", the Ministers also adopted a separate Declaration on TRIPS and Public Health which asserted that the TRIPS Agreement does not and should not hinder the efforts of WTO Member States aimed at

${ }^{156}$ See Joint Communication, Brazil-United States, 25 June 2001.

157 The US has applied pressure on other WTO Members, forcing them to change their policies. These include Argentina, the Dominican Republic, Kenya and Thailand. See Abbott FM "The Doha Declaration on the TRIPS Agreement and Public Health: Lighting a Dark Corner at the WTO" (2002) Journal of International Economic Law 469, 472.

158 Document WT/MIN(01)/DEC/1, 20 November 2001.

159 Ibid at para 6. 
protecting public health. ${ }^{160}$ The Declaration also reaffirmed the right of developing countries to employ safeguards under the Agreement to reduce the price of medicines and further requested WTO Members to find a solution for countries with insufficient generic manufacturing capacity. ${ }^{161}$ The LDC Members were afforded, on a without prejudice basis, an exemption from implementing or applying sections 5 and 7 of Part II of the TRIPS Agreement concerning pharmaceutical patents until 1 January 2016.

In August 2003, the TRIPS flexibility enhancement concerning pharmaceutical patents was implemented by a WTO decision allowing developing countries that do not have the capacity to manufacture pharmaceuticals to import cheap generic drugs made under compulsory licence in order to address public health problems. ${ }^{162}$ In December 2005, the General Council of the WTO took a decision which effectively transforms the August 2003 decision (termed the "paragraph 6 system") into a permanent amendment of the TRIPS Agreement. 163 The amendment will enter into force once two thirds of WTO Members have ratified it by the extended deadline of 31 December 2011. ${ }^{164}$ Until then, Members can still utilise the August 2003 decision as it stands. Although this mechanism is a potentially significant measure, it has been criticised by a number of organisations advocating access to medicines for being "too burdensome and unworkable in practice". 165

It has been contended further that the spirit and purpose of the Doha Declaration has been frustrated by the proliferation of free trade agreements (FTAs) which enjoin developing countries not to utilise TRIPS flexibilities or burden developing countries with unacceptably high standards of intellectual property protection

160 Document WT/MIN(01)/DEC/2, paras 1 and 4. Cf. EC-Measures affecting asbestos and asbestoscontaining products, WT/DS135/AB/R, 12 March 2001, para 168, where the WTO Appellate Body upheld the right of Member States "to determine the level of protection of health that they consider appropriate in a given situation".

161 Ibid at paras 4 and 6.0n 17 July 2007, Rwanda became the first Member State to inform the WTO that it was using the 30 August 2003 decision designed to ease the way for countries with public health problems to import cheaper generic drugs made under compulsory licensing in other countries when they are unable to manufacture the drugs themselves.

162 Implementation of paragraph 6 of the Doha Declaration on the TRIPS Agreement and Public Health, Decision of the General Council of 30 August 2003, Document WT/L/540 and Corr.1, 1 September 2003. The measure is known as the "paragraph 6 system". On 17 July 2007, Rwanda became the first Member State to inform the WTO that it was using the 30 August 2003 decision designed to ease the way for countries with public health problems to import cheaper generic drugs made under compulsory licensing in other countries when they are unable to manufacture the drugs themselves.

${ }_{163}$ Amendment of the TRIPS Agreement, Decision of 6 December 2005, Document WT/L/641, 8 December 2005.

164 As of 17 September 2010, only 31 of the WTO's 153 Members had ratified the amendment: Albania, Australia, Bahrain, Brazil, Canada, China, Colombia, Egypt, El Salvador, Hong Kong (China), India, Israel, Japan, Jordan, Macau (China), Mauritius, Mexico, Mongolia, Morocco, Nicaragua, Norway, Pakistan, Philippines, Republic of Korea, Singapore, Switzerland, Uganda, the Former Yugoslav Republic of Macedonia, the European Union (formerly the European Community), the US and Zambia. 165 See Joint Statement by NGOs on TRIPS and Public Health, WTO Members should reject bad deal on medicines, 3 December 2005 available at http://www.cptech.org/ip/wto/p6/ngos12032005.html (access confirmed: 28 March 2008). 
which far exceed the TRIPS standards (termed "TRIPS-plus" rules or conditions). ${ }^{166}$ Common restrictive measures in FTAs include the explicit limitation of TRIPS flexibilities or imposition of additional obligations, extension of patent terms, grant of "new use" patents, parallel import bans, and limitation of the grounds for issuance of compulsory licences. ${ }^{167}$ These measures can undermine Member States' obligations to ensure the enjoyment of the rights to health and life by making medicines more expensive. An example is the United States-Morocco Free Trade Agreement that was signed in March 2004 amidst severe criticism and entered into force on 1 January 2006. The FTA includes intellectual property rules that extend well beyond the TRIPS standard. ${ }^{168}$ These "TRIPS-plus" rules involve the extension of patent term, limitations on parallel imports of patented drugs, data exclusivity and market authorization restrictions. ${ }^{169}$ The FTA thus undermines the flexibilities reaffirmed by the Doha Declaration on TRIPS and Public Health and restricts Morocco's ability to take measures designed to reduce the cost of medicines and to ensure access to these by the poorest sections of its population.

In sum, while the Declaration can potentially mitigate the harmful effects of intellectual property rules, developed countries and the pharmaceutical companies have undermined its effectiveness in a variety of ways.

\subsection{The Agreement on Agriculture and Human Rights}

The Agreement on Agriculture (AoA) entered into force in 1995 as part of the WTO system. ${ }^{170}$ It is designed to further the aims of the organisation by "establishing a fair and market-oriented agricultural trading system". ${ }^{171}$ The Agreement includes specific commitments by Member States to enhance market access and reduce

166 Hestermeyer (fn 71 above). See also Oxfam (2006) fn 4 at 12-18. Between 2001 and 2006, the US had concluded 11 bilateral and regional FTAs with 23 countries. See Correa CM "Implications of Bilateral Free Trade Agreements on Access to Medicines" (2006) 84 Bulletin of the WHO 399 cited in Hestermeyer (fn 71above) at 289. The US has also applied other forms of pressure on developing countries to implement higher levels of intellectual property protection including monitoring other countries' intellectual property rules in relation to US standards (Special 301 reports) and introducing TRIPS-plus rules which makes the WTO accession process almost impossible for new members.

167 Examples of these provisions include the US-Chile FTA, article 17.10.2(a) (extension of patent term); US-Morocco FTA, article 15.9.2 ("new use" patents); US-Morocco FTA, article 15.9.4 and USAustralia FTA, article 17.9.4 (ban on parallel imports); and US-Jordan FTA, article 4.20 (grounds for compulsory licences).

168 3D Trade-Related Intellectual Property Rights, Access to Medicines and Human Rights - Morocco (2006) 3.

169 Ibid 4.

170 The Agreement is set out in Annex 1A to the Marrakesh Agreement.

171 Preamble to Agreement on Agriculture, para 2. See also Wouters and De Meester (fn 8 above) at 89-94; Bhala R "World Agricultural Trade in Purgatory: the Uruguay Round Agriculture Agreement and its Implications for the Doha Round" (2003) North Dakota Law Review 691-830; O'Connor B "A Note on the Need for More Clarity in the World Trade Organization Agreement on Agriculture" (2003) Journal of World Trade 839-846. 
trade-distorting subsidies in agriculture. ${ }^{172}$ Members were enjoined to implement these commitments over a six-year period (10 years for developing countries) which commenced in 1995.

\section{(a) Overview of Main Provisions}

The provisions of the AoA are in three main categories: market access, ${ }^{173}$ domestic support ${ }^{174}$ and export subsidies. ${ }^{175}$ First, the AoA seeks to increase international agricultural trade by reducing tariffs (i.e. border obstacles to trade such as taxes and duties). In this regard, Members are required to abolish restrictions on the quantity of agricultural products entering their markets ("quantitative restrictions") and not to maintain, resort to, or revert to any measures of the kind which have been required to be converted into ordinary customs duties, including variable import levies, minimum import prices, discretionary import licensing, non-tariff measures maintained through state-trading enterprises, voluntary export restraints or similar border measures. ${ }^{176}$ Under article 5, Members can indicate in their schedules that they regard certain agricultural products as potentially subject to "special safeguard provisions" which can be used to prevent import surges or drops in prices. A notable aspect of the market access commitments is that all Members, including the LDCs, have to bind all tariffs on agricultural products.

Second, article 6 of the AoA aims to reduce the level of domestic support provided by governments to their farmers since these directly distort trade and production. ${ }^{177}$ Such support includes subsidies for production of specific agricultural goods, guaranteed prices and agricultural infrastructure and research. Least developed countries have no reduction commitments.

Finally, article 9 of the AoA specifies export subsidies - government payments that cover the costs of exporting agricultural produce ${ }^{178}$ - which WTO Members are enjoined to reduce. It also prohibits the introduction of new subsidies. Again, LDC Members have no commitments in this regard.

Despite the commitments made by WTO Members under the Doha Declaration of 14 November 2001 concerning negotiations aimed at substantial improvements in market access reductions of all forms of export subsidies and substantial reductions in trade-distorting domestic support; as well as their agreement that special and

\footnotetext{
172 Wouters and De Meester (fn 8 above) 89.

173 Article 4.

174 Article 6.

175 Article 8.

176 In Chile-Price Band System and Safeguard Measures Relating to Certain Agricultural Products, WT/DS207/AB/R, par 200-201 (2002), the Appellate Body indicated that article 4 is "appropriately viewed as the legal vehicle for requiring the conversion into ordinary customs duties of certain market access barriers affecting imports of agricultural products".

177 Wouters and De Meester (fn 8 above) 90.

178 See Canada - Measures Affecting the Importation of Milk and the Exportation of Dairy Products (Canada-Dairy), WT/DS103/AB/R, par. 87 (1999).
} 
differential treatment for developing countries would constitute an integral part of the negotiations, there has not been much progress made in this regard. ${ }^{179}$

\section{(b) Human rights implications}

It is worth noting that the AoA does contain provisions that could protect particular countries or certain groups of people from the harmful effects of trade liberalisation and therefore facilitate a fairer trading system that is consistent with human rights. ${ }^{180}$ These include non-trade concerns (such as food security, rural development, rural livelihoods and protection of the environment), Special and Differential Treatment (designed to give developing countries greater flexibility in the implementation of WTO agreements), ${ }^{181}$ and the Special Safeguard (provided to countries that underwent tariffication in order to provide temporary protection to farmers in the event of spontaneous fluctuations in imports or falls in world commodity prices). While these measures are, for the most part, undefined and underutilised and implemented in a manner that does not ensure the protection of human rights, it can be argued that they nevertheless proffer an opportunity through which WTO Member States can, to some degree, fulfil their human rights obligations. It is notable, however, that developed countries often frustrate the effective implementation of these measures by failing to honour Special and Differential Treatment commitments or through attempts to weaken such provisions in WTO agreements.

When examining the human rights implications of the AoA, it is important to consider the impact of other factors such as the International Monetary Fund (IMF) and World Bank policies and, bilateral and regional trade arrangements which are all part of a broader trade liberalization agenda. Since the 1980s, the IMF and World Bank have prescribed economic austerity measures (structural adjustment programmes) in the context of which many developing countries have been constrained to reduce most of their trade barriers. ${ }^{182}$ This has negatively impacted on the ability of these countries to maintain better border protective measures or to implement domestic price controls. It has also affected their ability to harness sufficient resources to provide subsidies to their farmers struggling under the burden of cheap imports. In Ghana, for example, the removal of subsidies to smallscale tomato, rice and poultry farmers in the context of IMF and World Bank

\footnotetext{
179 Wouter and De Meester (fn 8 above) 93.

180 See 3D Planting the Rights Seed: A human rights perspective on agriculture trade and the WTO, Thread Backgrounder No 1 (2005) 6.

181 Thus, for instance, under art 15(2) of the AoA, LDCs are exempted from domestic support reduction commitments for low-income farmers in order to encourage rural development.

182 The ESCR Committee has taken a dim view of the human rights implications of IMF and World Bank structural adjustment policies. For example, in 2000, it stated that "some aspects of structural adjustment programmes and economic liberalization policies introduced by the Government of Egypt, in concert with international financial institutions, have impeded the implementation of the Covenant's provisions, particularly with regard to the most vulnerable groups of Egyptian society". See CESCR Concluding Observations: Egypt, Doc.E/C.12/1/Add.44 (2000).
} 
prescribed liberalization programmes, led to an influx of cheap imports of these products from the US, Europe and Asia, which local consumers opted for to the detriment of the local farmers whose competitiveness had been significantly reduced by the lack of subsidies. ${ }^{183}$

This situation does not apply to the developed countries who have not been subjected to IMF and World Bank trade liberalisation measures requiring the removal of trade barriers and who have sufficient financial resources to provide subsidies to their farmers.

From a human rights perspective, however, the AoA has a number of defects. First, its export-oriented trade liberalisation approach focuses more on increasing international trade rather than on improving the livelihoods of those that are engaged in agricultural production. ${ }^{184}$ Second, it fails to deal with the problem of dominance of TNCs in the food production sector and the dumping of cheap produce to the detriment of the livelihoods of small-scale farmers who are driven out of business and impoverished as a consequence. ${ }^{185}$ This underscores the need for WTO Members to regulate TNCs more effectively. ${ }^{186}$ Third, the AoA has locked developing countries into an unfair trading system which significantly diminishes their ability to adopt domestic trade policies that are consistent with human rights. ${ }^{187}$ All of these issues affect many internationally-recognised human rights, such as the rights to life, to an adequate standard of living (including the right to food), to health, to work and to education.

\section{(c) The AoA and the Right to Food}

The right to food is enshrined in several international human rights and other instruments. ${ }^{188}$ The right is dealt with comprehensively in the ICESCR. Under article 11(1) of this treaty, States Parties recognise "the right of everyone to an adequate standard of living for himself and his family, including adequate food, clothing and housing, and to the continuous improvement of living conditions". In terms of article

183 See 3D Integrating Human Rights into the Future of Agriculture, Report of a Workshop for human rights advocates on how to work to ensure that global agricultural policies are equitable and human rights consistent, Geneva, November 2004 available at http://www.3dthree.org/pdf 3D/ 3DAg+HRenglish-couleur.pdf (access confirmed: 30 January 2007).

184 It should be noted in this regard that according to the WTO Agreement, the organisation's aims are to raise living standards, ensure full employment and increase income. See 3D (fn 183 above) 8. $1853 \mathrm{D}$ (fn 183 above) 8.

186 Failure to do so in circumstances where the activities of TNCs violate human rights might result in the state concerned incurring liability for the violations. See Social and Economic Rights Action Centre (SERAC) and Another v Nigeria (2001) AHRLR 60 (ACHPR 2001).

187 It is notable that the obligation to cooperate internationally for the full realisation of human rights as set out in core human rights instruments implies that states have a duty to ensure that practices within their jurisdiction do not hamper other states' attempts to effectively implement their human rights obligations. See CESCR General Comment No 3: The Nature of States Parties Obligations (1990). 188 For example, UDHR, article 25; ICESCR, article 11(1) and (2); CRC, article 24(2)(c); Geneva Convention IV, article 89; Protocol II, article 14. 
11(2), States Parties recognise the need for immediate and urgent measures to ensure the "fundamental right to freedom from hunger and malnutrition".

The ESCR Committee has defined the normative content of the right to adequate food in the following terms:

The right to adequate food is realised when every man, woman and child, alone or in community with others, have physical and economic access at all times to adequate food or means of its procurement.... The core content of the right to adequate food implies the availability of food in quantity and quality sufficient to satisfy the dietary needs of individuals, free from adverse substances, and acceptable within a given culture; [and] the accessibility of such food in ways that are sustainable and that do not interfere with the enjoyment of other human rights. 189

In this context, availability refers to the possibilities either for feeding oneself directly from productive land or other natural resources, or for properly functioning distribution, processing and market systems that can move food from the place of production to the place of consumption in accordance with demand. The principle of accessibility encompasses both economic and physical accessibility. Economic accessibility implies that personal and household expenditure associated with the acquisition of food for an adequate diet should be at a level such that the fulfilment of other basic needs are not threatened or compromised. Physical accessibility implies that adequate food must be accessible to everyone, especially persons belonging to physically vulnerable groups. ${ }^{190}$

The right to food, like other human rights, imposes three types of obligations on States Parties to treaties enshrining the right: the obligations to respect, to protect and to fulfil. The obligation to respect existing access to adequate food requires States Parties not to take any measures that could hinder such access. The obligation to protect requires the State to take measures to ensure that third parties do not deprive individuals of their access to adequate food. In the SERAC case, the African Commission held that the right to food obliges states to protect and improve existing food sources and to ensure access to adequate food for all citizens. ${ }^{191}$ As a minimum, the right to food requires that states must refrain from destroying or contaminating food sources or preventing people's efforts to feed themselves. The Commission concluded that by allowing private companies to destroy food sources, the Nigerian government had not fulfilled its obligations under the ACHPR and international human rights instruments and was therefore in violation of the Ogoni people's right to food. ${ }^{192}$ This decision has significant implications for the regulation,

189 CESCR General Comment No. 12: The Right to Adequate Food (Art 11), Doc.E/C.12/1999/5 (1999), para 3.

190 These include infants and young children, elderly people, the physically disabled, and the terminally ill.

${ }^{191}$ See fn 186 above.

192 See also Commission Nationale des Droits de l'Homme et des Libertes v Chad (2000) AHRLR 66 (ACHPR 1995) where the African Commission found that the obligation in Article 1 of the ACHPR to "undertake ... measures to give effect" to the rights in the ACHPR entails that if a state neglects to 
by African states, of the activities of TNCs that may pose a threat to the livelihoods of their citizens and therefore also has implications for these States' commitments under the AoA.

The obligation to fulfil human rights requires the State to proactively undertake activities calculated to enhance people's access to and utilization of resources and means to ensure their livelihood, including food security and to provide the right directly to individuals or groups that are unable, for reasons beyond their control, to enjoy the right to adequate food. Where a State fails to ensure the satisfaction of, at least, the minimum essential level required to be free from hunger, it would be in violation of the right to adequate food. It should be noted that violations of the right to food can occur through the direct action of the State or other entities insufficiently regulated by the State. ${ }^{193}$

It is important to note that there are many dimensions to the right to food and its full realisation depends on a variety of factors, such as access to productive resources and paid employment. The right is also linked to other human rights, including the right to health, property rights (especially land rights), labour rights, access to justice and the right to information and education. ${ }^{194}$

\section{(d) Free trade and the Right to Food}

As in the case of most WTO agreements, the AoA is premised on free trade or trade liberalization. Proponents of trade liberalization argue that trade barriers are a costly and ineffective way of enhancing food security and development in poor countries. ${ }^{195}$

Conversely, opponents of free trade maintain that the free trade agenda fails to account sufficiently for the inequitable power relations between developed and developing countries that characterise the multilateral trade negotiation process. In their estimation, trade liberalisation jeopardises food security because it benefits only the larger and export-oriented farmers and marginalises small farmers and ultimately creates unemployment and poverty. They further contend that agricultural imports from developed countries expose food consumers to price shocks and small producers to risks and disincentives.

ensure the rights in the Charter this would constitute a violation even if the state or its agents are not the immediate cause of the violation.

${ }^{193}$ See the Commission Nationale des Droits de l'Homme et des Libertes case (fn 193 above) and the SERAC case (fn 186 above).

194 Vidar M "The Interrelationships between the Right to Food and Other Human Rights" in Eide and Kracht (fn 136 above). See also the SERAC case (fn 186 above), where the African Commission observed that the right to food is inseparably linked to human dignity and is as such essential for the enjoyment and fulfilment of such other rights as health, education, work and political participation.

195 FAO The State of Food and Agriculture 2005 (2005) 3. According to the Food and Agriculture Organization (FAO), "multilateral trade offers opportunities for the poor and food-insecure by acting as a catalyst for change and by promoting conditions in which the food-insecure are able to raise their incomes and live longer, healthier and more productive lives" (at 6). 
While agricultural trade liberalization can create export opportunities in agricultural exporting countries and promote growth and development, it may also have adverse implications especially for small scale farmers and for food security. As the OHCHR has observed:

Small farmers might not have the capacity to grow sufficient export crops and might even experience greater competition for resources, including land, thus marginalizing them from the potential benefits of trade. Similarly, greater export opportunities might lead to reallocation of land and other resources away from domestic food production, with possible adverse consequences for household food security. ${ }^{196}$

It is notable that while the FAO which has highlighted the benefits of trade liberalisation it has also acknowledged that trade liberalization can have adverse effects:

Opening national agricultural markets to international competition - especially from subsidized competitors - before basic market institutions and infrastructure are in place can undermine the agriculture sector, with long-term negative consequences for poverty and food security. ${ }^{197}$

Illustratively, a 1999 study by the FAO evaluating the impact of the AoA on agricultural trade and food security in developing countries noted that while asparagus was the most dynamic export crop in Peru in the 1990s, the producers were mainly large scale farmers, not poor farmers. ${ }^{198}$ It concluded that the poor were likely to be the most adversely affected by open trade policies. ${ }^{199}$ In similar vein, the liberalization of maize in Zambia caused the producer price to fall and the consumer price to increase. As a consequence, there was a 20 per cent drop in maize consumption and an attendant increase in malnutrition and mortality. Owing to increased levels of poverty, health indictors declined and many families were unable to send their children to school. 200

Thus, in order to minimize the adverse effects of trade liberalization, governments need to implement policies that complement trade reforms and enable the poor to take advantage of trade-related economic opportunities, while establishing safety nets to protect vulnerable members of society. ${ }^{201}$ As the OHCHR has observed, without the introduction of appropriate safeguards and transitional measures, trade rules could have adverse effects on the right to food, the rights of workers and other rights of small-scale farmers and the rural poor. ${ }^{202}$ However, it is

196 OHCHR (fn 95 above) 2. See also FAO Agriculture, Trade and Food Security: Issues and Options in the WTO Negotiations from the Perspective of Developing Countries Vol II (2000).

197 FAO WTO Agreement on Agriculture: The Implementation Experience - Developing Country Case Studies (2003) 6.

198 Ibid.

199 Ibid.

$2003 \mathrm{D}$ (fn 183 above).

${ }^{201}$ See FAO Agriculture Trade and Poverty - Can Trade Work for the Poor (2005) 6.

202 OHCHR (fn 95 above) 2. 
difficult to see how developing countries would manage this, especially in the present international trade climate of distorted commodity markets and in which some developed countries retain import barriers, export subsidies and domestic support contrary to the spirit of the AoA. As stated above, the right to food includes both food security and the provision of employment opportunities. In the developing countries, the agricultural sector is not only the source of most of the food consumed, it is also the major source of employment.

While States are ultimately responsible for the realisation of the right to food in relation to persons under their jurisdiction, the ESCR Committee has emphasised the importance of international assistance and cooperation, especially "economic and technical". ${ }^{203}$ The implications of this are, inter alia, that States Parties should respect the enjoyment of the right to food in other countries, protect that right, facilitate access to food and provide the necessary aid when required; and ensure, in relevant international agreements, that the right to food is given due attention.

\section{CONCLUSION}

Since its establishment just over a decade ago, the WTO has become one of the most influential international organisations. Its key purpose is to liberalize trade with the ultimate aim of promoting growth and economic development and raising living standards. In recent years, however, the organization's trade liberalization agenda and its perceived lack of accountability and transparency have attracted intense criticism.

While it is generally accepted that trade has an important role to play in improving livelihoods, studies indicate that trade liberalization has not necessarily achieved this result for many of the WTO Members. Critics assert that the WTO agreements, most of which are based on the free trade ideal, ignore the unequal power relations inherent in negotiations between the developed and developing countries and that they pose a threat to the very livelihoods that the organization ostensibly seeks to improve as well as to human rights. While these agreements contain certain flexibilities that would, if effectively utilised, contribute to the realisation of human rights, these flexibilities have been rendered ineffective by developed countries through measures such as the adoption of TRIPS-plus rules in FTAs and the exertion of unilateral economic pressure. Consequently, it is contended that trade liberalization has in fact created an unjust global trading order in which rich countries are benefiting at the expense of poor countries and the latter are increasingly placed in a situation where they are unable to give full effect to their commitments under international human rights treaties.

This situation underscores the need for the WTO and its Members to adopt a human rights approach in the design, implementation and assessment of trade

\footnotetext{
${ }^{203}$ See General Comment No 3 (fn 189 above) para 13.
} 
liberalization policies. This will afford those affected by trade policy the opportunity to participate more effectively in the formulation of trade policies to ensure that such policies are more transparent, accountable and responsive to the needs of the people they are designed to serve. Further, flexible or innovative interpretation of the WTO rules by the organisation's dispute settlement mechanism will arguably also enhance the prospects for the protection and promotion of human rights, albeit indirectly and in a limited manner.

Finally, it is important to emphasise that states bear the primary responsibility for ensuring the protection and promotion of the rights to health and adequate food. Although the TRIPS and AoA place limitations on how WTO Members regulate trade, national governments retain a range of options that they can pursue to ensure the realisation of the rights to health and food in an era of trade liberalization. However, the flexibilities proffered by these agreements need to be utilised to the fullest extent possible if they are to be effective from a human rights perspective. Further, WTO rules must not reduce or undermine the ability of Member States to meet their human rights obligations to persons within their territories and subject to their jurisdiction. As the primary bearers of obligations under international human rights law, States must also carry out human rights impact assessments before undertaking new commitments under bilateral and multilateral trade agreements. 


\section{BIBLIOGRAPHY}

3D Integrating Human Rights into the Future of Agriculture, Report of a Workshop for human rights advocates on how to ensure that global agricultural policies are equitable and human rights consistent (2004).

3D Planting the Rights Seed: A human rights perspective on agriculture trade and the WTO, Thread Backgrounder No 1 (2005).

3D Trade-related intellectual property rights, access to medicines and human rights Morocco (2006).

Abbott FM "The Doha Declaration on the TRIPS Agreement and Public Health: Lighting a Dark Corner at the WTO" (2002) Journal of International Economic Law (2002) 469-505.

AIDS Law Project and TAC The Price of Life: Hazel tau and Others $v$ GlaxoSmithKline and Boehringer Ingelheim: A Report on the Excessive Pricing Complaint to South Africa's Competition Commission (2003).

Baker BK Processes and issues for Improving Access to Medicines: Willingness and Ability to Utilise TRIPS Flexibilities in Non-Producing Countries (2004).

Bhala R 'World Agricultural Trade in Purgatory: The Uruguay Round Agriculture Agreement and its Implications for the Doha Round' (2003) North Dakota Law Review 691.

Chaudhuri S Goldberg PK and Jia P 'The Effects of extending Intellectual Property Rights Protection to Developing Countries: A Case Study of the Indian Pharmaceutical Market' NBER Working Paper 10159 (2003).

Correa CM Intellectual Property Rights, the WTO and Developing Countries: The TRIPS Agreement and Policy Options (2000).

Correa, CM Trade Related Aspects of Intellectual Property Rights: A Commentary on the TRIPS Agreement (2007).

Dommen C 'Raising Human Rights Concerns in the World Trade Organization: Actors, Processes and Possible Strategies' (2002) 24 Human Rights Quarterly 1.

Eide A "The Importance of Economic and Social Rights in the Age of Economic Globalization" in Eide WB and Kracht U (eds) Food and Human Rights in Development Vol I: Legal and institutional dimensions and selected topics (2005) 340.

FAO Agriculture, Trade and Food Security: Issues and Options in the WTO Negotiations from the Perspective of Developing Countries Vol II (2000).

FAO The State of Food and Agriculture: Agriculture Trade and Poverty - Can Trade Work for the Poor (2005). 
FAO WTO Agreement on Agriculture: The Implementation Experience - Developing Country Case Studies (2003).

Fink C "How Stronger Patent Protection in India Might Affect the Behaviour of Transnational Pharmaceutical Industries" World Bank Working Paper No 2352 (2000).

Gervais D The TRIPS Agreement: Drafting History and Analysis (2003).

Hestermeyer H Human Rights and the WTO: The Case of Patents and Access to Medicines (2007).

Hoekman B and Kostecki M The Political Economy of the World Trading System: The WTO and Beyond (2001).

Kanji N and Barrientos S Trade Liberalisation, poverty and livelihoods: understanding the linkages (2002).

McCulloch N Winters LA and Cirera, X Trade Liberalization and Poverty: A Handbook (2002).

Mushayavanhu D "The realisation of access to HIV and AIDS-related medicines in Southern African countries: Possibilities and actual realisation of international law obligations" in Viljoen F and Precious S (eds) Human Rights under threat: Four perspectives on HIV, AIDS and the Law in Southern Africa (2007) 127.

O'Connor B "A Note on the Need for More Clarity in the World Trade Organization Agreement on Agriculture" (2003) Journal of World Trade 839.

OHCHR Human Rights and World Trade Agreements: Using General Exception Clauses to Protect Human Rights (2005).

Oxfam Cut the Cost, Patent Injustice: How World Trade Rules Threaten the Health of Poor People (2001).

Oxfam Patents versus Patients: Five Years after the Doha Declaration Oxfam Briefing Paper (2006).

Oxfam Rigged Rules and Double Standards: Trade, Globalization, and the Fight Against Poverty (2002).

Subramanian A "The AIDS Crisis, Differential Pricing of Drugs and the TRIPS Agreement: Two Proposals" (2001) 4 Journal of World Intellectual Property 323.

Thomas JS and Meyer MA The New Rules of Global Trade: A Guide to the World Trade Organization (1997).

UNDP Human Development Report (1999).

Velasquez G and Boulet P Globalization and Access to Drugs: Implications of the WTO/TRIPS Agreement Health and Drugs DAP Series No 7, 2 ed (1999). 
Vidar M "The Interrelationships between the Right to Food and Other Human Rights" in Eide WB and Kracht U (eds) Food and Human Rights in Development Vol I: Legal and institutional dimensions and selected topics (2005) 141-160.

WHO/UNAIDS/MSF "Determining the patent status of essential medicines in developing countries" Health Economics and Drugs, EDM Series No 17 (2004).

WHO/UNAIDS/UNICEF Towards Universal Access: Scaling up priority HIV/AIDS interventions in the health sector, Progress Report (2007).

Wouters J and De Meester B The World Trade Organization: A Legal and Institutional Analysis (2007). 